\title{
THE EFFECT OF FINANCIAL LITERACY AND PERSONALITY TOWARDS STUDENTS' FINANCIAL MANAGEMENT ABILITY
}

\author{
Nur Fitrah Ramadhani Liesfi ${ }^{1 *}$ \\ Yogyakarta State University \\ 1, Colombo St., Sleman \\ Indonesia 55281 \\ nfitrahr1.2017@student.uny.ac.id
}

\author{
Suranto Suranto ${ }^{2}$ \\ Yogyakarta State University \\ 1, Colombo St., Sleman \\ Indonesia 55281 \\ suranto@uny.ac.id
}

\begin{abstract}
This study aims to find out the effect of financial literacy and personality traits on personal financial management. The population in this study was all students of the Faculty of Economics, which consisted of 1068 students, and 258 students were selected as the samples of this study using a proportional cluster random sampling system. The data analysis technique used was multiple linear regression. The result of this study showed that financial literacy and personality, whether simultaneous or partial, significantly and positively affect the personal financial management of students.
\end{abstract}

Keywords: Financial Management; Financial Literacy; Personality; College Student

\section{ABSTRAK}

Penelitian ini bertujuan untuk mengetahui pengaruh literasi keuangan dan ciri-ciri kepribadian terhadap pengelolaan keuangan pribadi. Populasi dalam penelitian ini adalah seluruh mahasiswa Fakultas Ekonomi yang berjumlah 1068 mahasiswa dan dipilih sebanyak 258 mahasiswa yang digunakan sebagai sampel dalam penelitian ini dengan menggunakan teknik proportional cluster random sampling. Teknik analisis data yang digunakan adalah regresi linear berganda. Hasil dari penelitian ini menunjukkan literasi keuangan dan kepribadian, baik secara simultan ataupun parsial, berpengaruh positif dan signifikan terhadap pengelolaan keuangan pribadi mahasiswa.

Kata Kunci: $\quad$ Pengelolaan Keuangan; Literasi Keuangan; JEL Classification: D14; G40; G53

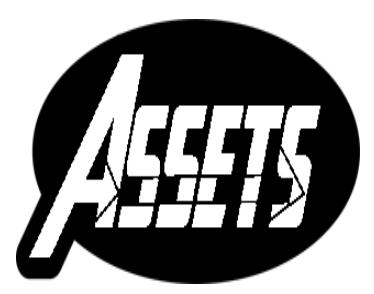

ASSETS

Jurnal Akuntansi dan Pendidikan

Vol. 10 No. 2

Page 101-110

Madiun, October 2021 p-ISSN: 2302-6251 e-ISSN: 2477-4995

Article History Submitted: February 19, 2020 Accepted: October 15, 2021 


\section{INTRODUCTION}

The massive development of technology has significantly given practicality in all aspects of life. Besides the positive impacts that occur, there are also adverse effects from that phenomenon. Consumptive behavior is one of the harmful effects of the practicality of transactions. Among students, consumptive behavior is seen as a normal lifestyle. Students can spend their money conveniently and easily provoke advertisements to have new brand stuff (Rohman, 2016). Students' needs are related to the living cost and college tuition and lifestyle, and prestige in this stage. Young people start to spend more money on entertainment and lifestyle, becoming more aware of brands (Birari \& Patil, 2014). If students do not manage their money well, they will face grave financial problems such as monthly money that runs out prematurely as a consequence. (Herdjiono \& Damanik, 2016) state that consumptive behavior makes someone unable to have saved, invest, make an emergency financial plan, and future budgeting.

Financial Management Behavior is the ability of someone to manage, budget, evaluate, control, earn and save money in daily life (Kholilah \& Iramani, 2013). Good financial management is essential for every person. Being aware of financial management is very important, especially in making a decision that affects prosperity (Chotimah \& Rohayati, 2015). sound financial management ability is urgently needed, significantly differentiating between need and will to gain prosperity and good financial achievement (Fatimah, 2018). State that someone's financial management depends on the knowledge and the understanding of concepts in financial literacy.

Financial literacy by Atkinson \& Messy (2011) is known as the combination of awareness, knowledge, ability, attitude, and behavior needed to make the financial decision to achieve financial well-being. People in Indonesia already recognize the product and financial services. However, many people still use the services and products without a good understanding. It is provided by a survey from the Financial Services Authority (2016), which mentions that the index of financial literacy index in Indonesia is $29,66 \%$. Meanwhile, the index of financial inclusion reaches $67,82 \%$. Students in the university also experience a poor understanding of financial literacy. Durband \& Britt (2012) state that students are in the assimilation process with the university environment, which leads to various financial problems such as the increase of tuition fees, unexpected costs, or various kinds of loans. Young people are frequently trapped in loan and credit card debt, preventing them from gathering richness and achieving prosperity (Lusardi, Mitchell, \& Curto, 2010). According to Chen \& Volpe (1998), students with low financial literacy levels tend to make wrong financial decisions and have bad financial behavior.

Besides financial literacy, personality is also an important factor to consider concerning financial management ability. Personality is a unique characteristic that is relatively permanent and stable in providing consistency for someone's behavior (Jess \& Gregory, 2014; Ewen, 1998). According to Sina (2014) to be successful in managing personal financial management, someone should understand the personality aspects because there is the difference found in managing finance for every type of personality. (Brown \& Taylor, 2011) mentions that personality affects family finance related to debt, asset ownership, and financial decision-making. Besides, there is the difference of personality found in women related to pension savings and risk tolerance which will affect the financial behavior (Lown, 2008). Subiaktono (2013) state that some personality traits such as agreeableness, conscientiousness, body focus, materialism, dan need for arousal have significant effects on the family financial plan, which is the part of financial management. 
Based on that idea, this study contributes to the literature that the essential factor in financial management is financial knowledge and the implementation in daily life. Previous research on financial management (Herdjiono \& Damanik, 2016; Bhargava, Mittal, \& Kushwaha, 2017; Sarath Chandran \& Chandran, 2018; Fatimah, 2018) frequently used financial knowledge as an independent variable. Therefore, other than that from the knowledge aspects, financial literacy should also be seen from the psychology aspect in personality. Although it is rarely related to financial management, personality differences should also be noticed because they can differentiate how someone manages their finances (Lown, 2008; Subiaktono, 2013). This study will examine the level of financial literacy and personality traits that positively affect the ability of personal financial management. This study aims to provide empirical proofs regarding financial literacy and personality that will significantly affect students' financial management.

\section{METHOD}

Using the multiple linear regression analysis techniques, this study investigates the causality among variables, also known as associative-causal research. The data used were primary data from students of the Faculty of Economics in Yogyakarta State University as the respondents in the research. The primary data related to the research variable were obtained from interviews and questionnaires. The population in this study was the students of the Faculty of Economics which consisted of 1068 students. From the population, 258 students were selected using the proportional cluster random sampling technique. The following is the regression equation in this study.

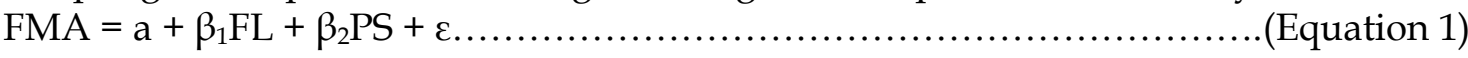

Description:

$$
\begin{array}{ll}
\mathrm{a} & =\text { Konstanta } \\
\beta & =\text { Beta } \\
\varepsilon & =\text { Error } \\
\text { FMA } & =\text { Financial Management Ability } \\
\text { FL } & =\text { Financial Literacy } \\
\text { PS } & =\text { Personality }
\end{array}
$$

Table 1. Population and Research Samples

\begin{tabular}{lrlr}
\hline \multicolumn{1}{c}{ Study Program } & Population & Calculation & Selected Numbers \\
\hline Office Administration & 174 & $\frac{174}{1068} \times 258=42,03 \rightarrow 42$ & 42 \\
Education & 221 & $\frac{221}{1068} \times 258=53,38 \rightarrow 53$ & 53 \\
Accounting Education & 200 & $\frac{200}{1068} \times 258=48,31 \rightarrow 48$ & 48 \\
Economics Education & 259 & $\frac{259}{1068} \times 258=62,56 \rightarrow 63$ & 63 \\
Management & 214 & $\frac{214}{1068} \times 258=51,69 \rightarrow 52$ & 52 \\
Accounting & 1068 & & 258 \\
Total & &
\end{tabular}

Source: Academic affairs of the Faculty of Economics (2019)

The determination of samples used the model developed by Issac and Michael (Sugiyono, 2016) with the population consisted of 1068 in the error level 5\%, which can be seen in Table 1. 


\section{RESULT AND DISCUSSION}

The respondents were asked to provide demographic data, including gender, study program, and semester. Of the total 258 respondents, $73 \%$ were women, and $27 \%$ were men. In terms of study programs of participants, Management was 24,5\%, Accounting Education was 20,3\%, Accounting was 20,2\%, then Economics Education was $18,6 \%$, and the rest was from Office Administration Education which was 16,4\%. Based on the semester of respondents, $57 \%$ of respondents were in the third semester, $38 \%$ were in the fifth semester, and $5 \%$ were in the seventh semester.

Table 2. Demographic Data of Respondents

\begin{tabular}{lrr}
\hline \multicolumn{1}{c}{ Description } & Total & Percentage \\
\hline Gender & & $27 \%$ \\
Male & 70 & $73 \%$ \\
Female & 188 & \\
Study Program & & $24,5 \%$ \\
Management & 63 & $20,3 \%$ \\
Accounting Education & 53 & $20,2 \%$ \\
Accounting & 52 & $18,6 \%$ \\
Economics Education & 48 & $16,4 \%$ \\
Office Administration Education & 42 & \\
Semester & & $57 \%$ \\
3 & 147 & $38 \%$ \\
5 & 98 & $5 \%$ \\
7 & 13 & \\
\hline
\end{tabular}

Table 3. Descriptive Statistics

\begin{tabular}{lrrrrr}
\multicolumn{1}{c}{ Variable } & N & \multicolumn{1}{c}{ Minimum } & Maximum & Mean & \multicolumn{2}{c}{ Std. Deviation } \\
\hline FMA & 258 & 18 & 72 & 45 & 9 \\
FL & 258 & 17 & 68 & 42,5 & 8,5 \\
PS & 258 & 22 & 88 & 55 & 11 \\
\hline
\end{tabular}

Table 4. The Categorization of Variable

\begin{tabular}{lllrr}
\hline \multicolumn{1}{c}{ Variable } & Category & Interval Value & Frequency & Percentage \\
\hline FMA & High & $X \geq 54$ & 73 & $28,3 \%$ \\
& Medium & $36 \leq \mathrm{X}<54$ & 183 & $70,93 \%$ \\
& Low & $\mathrm{X}<36$ & 2 & $0,77 \%$ \\
FL (Chen \& & High & $>80 \%$ & 59 & $23 \%$ \\
Volpe, 1998) & Medium & $60 \%-80 \%$ & 180 & $70 \%$ \\
& Low & $<60 \%$ & 19 & $7 \%$ \\
PS & High & $\mathrm{X} \geq 66$ & 73 & $28,3 \%$ \\
& Medium & $44 \leq \mathrm{X}<66$ & 185 & $71,7 \%$ \\
& Low & $\mathrm{X}<44$ & 0 & $0 \%$ \\
\hline
\end{tabular}

The variable statistic testing of financial management ability, financial literacy, and personality can be seen in Table 3. From Table 3, the data are then categorized, so the explanation of each variable can be described in Table 4 .

Table 4 shows the categorization of each variable. Overall, students already have good financial management ability (in the high and medium categories), although there are still two students in the low category. However, those two students come from the office administration education study program, which gets more minor http:// doi.org/10.25273/jap.v10i2.6048 
finance courses than the other programs. They got a course related to finance, namely financial administration, in the fifth semester. Meanwhile, when classified by gender, male and female respondents were not much different. In the low category, there was one male and one female respondent.

Meanwhile, in the high category, there were $27 \%$ male and $30 \%$ female. The study's finding (Birari \& Patil, 2014) stated no significant difference by gender in expenditure. Norvilitis et al. (2006) also said that the role of gender in debt is not clear, and there is no fundamental difference regarding credit card ownership, which means that both men and women have similar financial management abilities.

Seven percent of respondents fell into the low category for the financial literacy variable, while the remaining 93\% were divided into medium and high categories. It probably occurs because the respondents are students with majors related to business and finance. A research finding from Beal \& Delpachitra (2003), Lantara \& Kartini (2015) finds that students majoring in business and finance tend to have better financial literacy than the students from the other programs. Furthermore, having a course in the personal finance or being a business major student will help increase your knowledge of spending (Robb \& Sharpe, 2009). The respondents in the high category or answered the most questions correctly were $28,5 \%$ male respondents and 20,7\% female respondents. It is in line with research conducted by Ergün (2018) which showed that male students possessed more knowledge about financial literacy than female students. Most of the respondents were in the moderate category on the personality variable, which was $71,7 \%$, and $28,3 \%$ were in the high category. None of them was in a low category. The high category means that the respondent has a simple personality and is not extravagant in managing finance.

Table 5 . The result of the t-test

\begin{tabular}{llrrl}
\hline & $\mathrm{B}$ & $\mathrm{t}$ & \multicolumn{1}{c}{ Sig. } & Description \\
\hline (Constant) & 1,086 & 6,445 & 0,000 & \\
Financial Literacy & 0,465 & 10,221 & 0,000 & Affect positively \\
Personality & 0,124 & 2,335 & 0,020 & Affect positively \\
\hline
\end{tabular}

\section{The Effect of Financial Literacy towards the Financial Management Ability}

Based on table 5, the financial literacy variable has $B$ value $=0,465, \mathrm{t}$ value $=$ 10,221 , and Sig value. 0,000 . The Sig. value $<0,05$ means an influence of the financial literacy variable on the financial management ability variable. The higher the students' financial literacy, the better their financial management will be. It can be said that financial literacy is one of the determining factors for good or bad students' financial management. Overall, students' financial literacy is quite good. It can be seen from Figure 1 that students' knowledge of savings, loans, insurance, and investment is quite good, with a percentage above $70 \%$. Meanwhile, the lowest percentage is $68,93 \%$ in the aspect of basic knowledge. According to Lantara \& Kartini (2015), this happens because most of the curriculum on finance at universities in Indonesia still focuses on corporate finance and the capital market and does not emphasize the personal finance aspect.

Good financial literacy is fundamental for young people or students in order to have good financial management ability. (Albeerdy \& Gharleghi, 2015) said that they were faced with the choice of a wide variety of financial products and services during these times. In addition, students are also in a period where they are starting to be required to manage finances independently without parental supervision (Akben- 
Selcuk, 2015). Therefore, good financial literacy is urgently needed to make the right choices in making financial decisions and avoid financial problems. The emergence of financial problems is due to low income and errors in managing finances (Yushita, 2017). The result of this study is in line with research conducted by Laily (2013), which found out that financial literacy affects personal financial management. Research from Lajuni, Bujang, Karia, \& Yacob (2018) sees that financial behavior and financial knowledge affect personal financial difficulties. The study said that the better a person's financial behavior and knowledge, the fewer financial difficulties. In other words, the person has better personal financial management abilities.

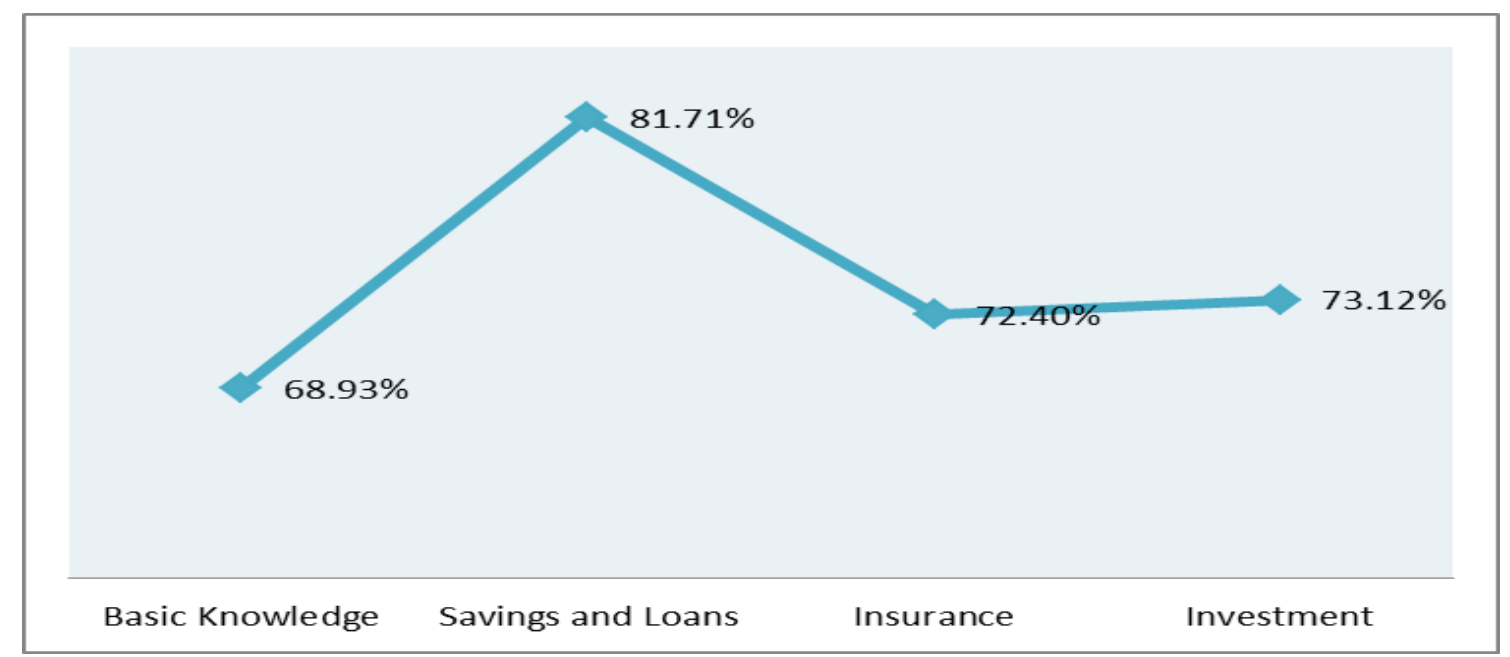

Figure 1. Financial Literacy of Respondents in Every Aspect

\section{The Effect of Personality towards Financial Management Ability}

The personality variable has a $B$ value of $0,124, t$ value $=2,335$, and Sig value. 0,020 . The Sig. value $<0,05$ indicates that the personality variable influences the financial management ability variable. These results are in line with the research finding (Humaira \& Sagoro, 2018; Donnelly, Iyer, \& Howell, 2012), which find out that personality influences financial management. Meanwhile, Sina (2014) also said that personality determines how a person manages his finances.

Figure 2 shows the percentage of personality traits possessed by respondents. The most prominent personality is agreeableness with $83,52 \%$, followed by conscientiousness, body focus, need for arousal, and in the last place is materialism with a percentage of $53,65 \%$, which means 138 respondents have this kind of personality in themselves. A person with the conscientiousness personality trait tends to have good financial management abilities. In contrast, someone with the materialism personality trait tends to be bad at controlling expenses and managing finances (Donnelly et al., 2012).

In table 4, there are no students included in the low category for the personality variable, which means their financial management abilities are pretty good. Then in Figure 2, although there is still a personality trait of materialism, it has the lowest percentage of $53,65 \%$. Materialism personality traits need more attention than others concerning financial management. Richins \& Dawson (1992) stated that a person with a material value believes that acquiring luxury and expensive goods is a life goal, an indicator of success, and the key to happiness. These things make it someone who has materialism as their personality trait easy to spend money on luxury goods. 


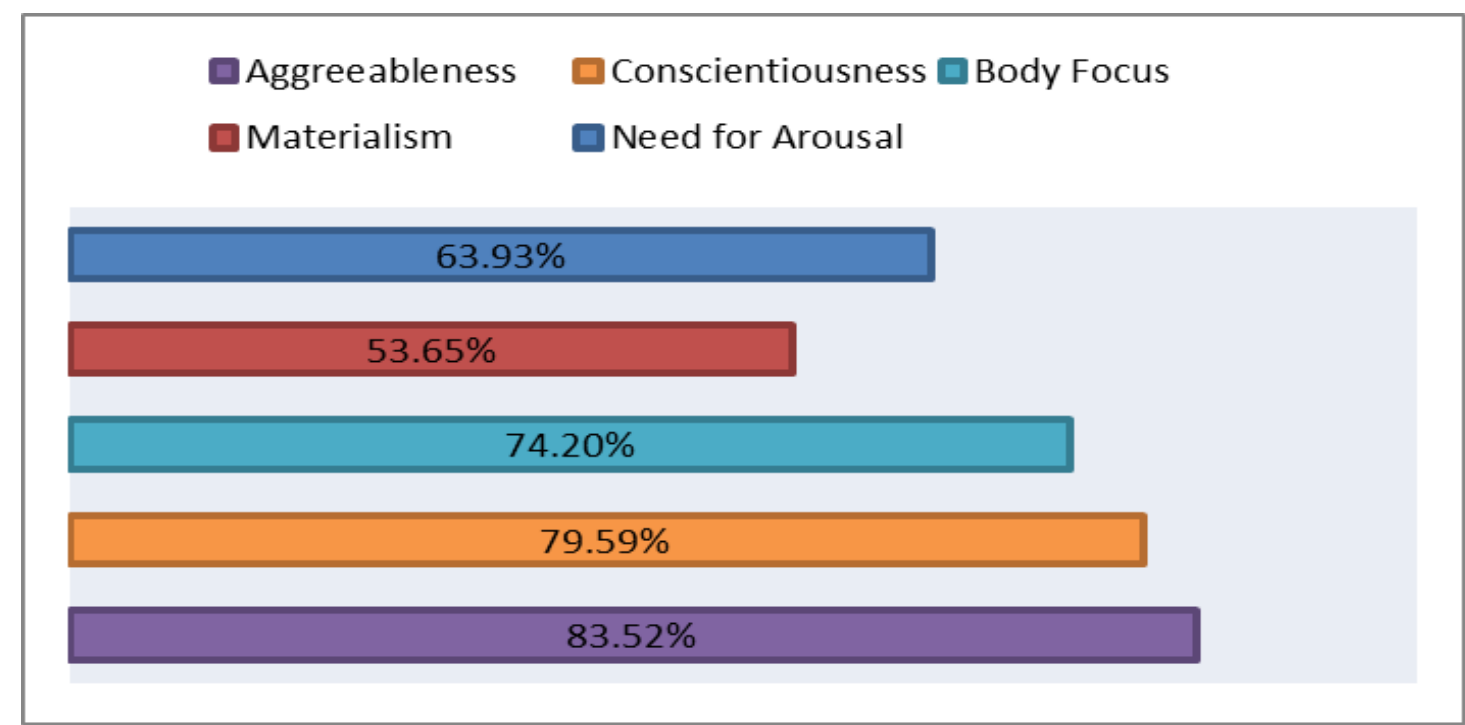

Figure 2. Personality Traits

The Effect of Financial Literacy and Personality towards the Financial Management Ability

Based on the research finding, financial literacy, and personality influence financial management ability. That can be interpreted as the higher the financial literacy and personality, the higher the financial management ability. This study has an $\mathrm{R}$ Square $\left(\mathrm{R}^{2}\right)$ of 0,349 , which means that the contribution of financial literacy and personality variables to financial management ability is 34,9\%, and the rest comes from the other variables. An overview of students' financial management ability can be seen in Figure 3. The highest aspect is saving, investing, debt, and billing, which is $73,72 \%$.

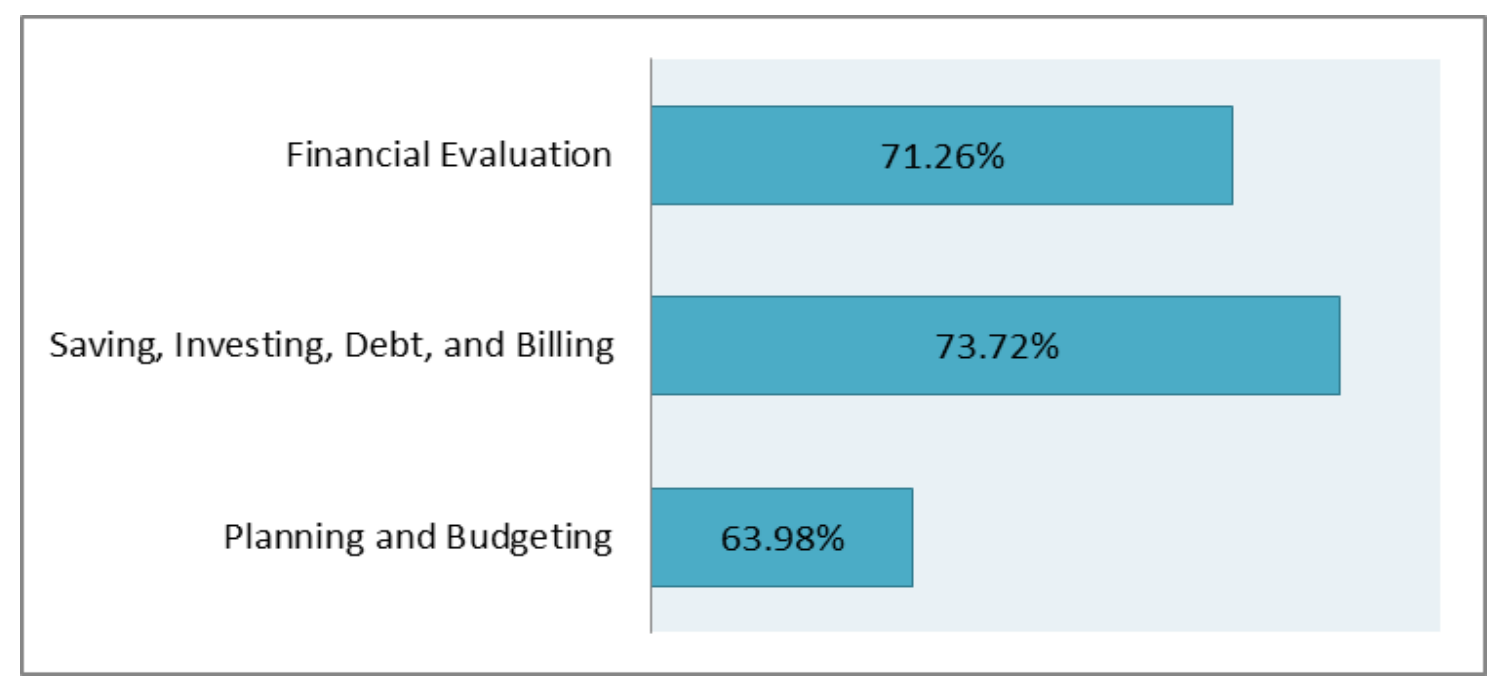

Figure 3. The Management of Students' Finance

It happens because students are used to these activities in their daily lives. Even students are used to doing it, such as paying bills at the end of the month or saving when they want to buy something. Financial evaluation is at $71,26 \%$, and the aspect of planning and budgeting is at $63,95 \%$. The low aspect of planning and budgeting can be caused by the assumption that was doing financial planning and budgeting. 


\section{CONCLUSION}

The result showed a positive and significant influence of financial literacy and personality on students' financial management ability, either partially or simultaneously. It shows that the higher the financial literacy and personality, the higher the student's financial management ability.

This study implies that students should continue to improve their financial literacy and always have attitudes and behaviors that reflect a simple and not extravagant personality. The limitation of this research is that the data collection is done using the questionnaire method, so that the researcher cannot control the answers given by the respondents. Researchers believe in the accuracy of the answers given, but there is a possibility that respondents do not provide answers that describe the actual situation. In addition, further research is expected to use other psychological aspects such as emotional intelligence. Furthermore, it can also be developed to find ways of sound financial management according to the various personalities that exist.

\section{REFERENCES}

Akben-Selcuk, E. (2015). Factors Influencing College Students' Financial Behaviors in Turkey: Evidence from a National Survey. International Journal of Economics and Finance, 7(6), 87-94. https://doi.org/10.5539/ijef.v7n6p87

Albeerdy, M. I., \& Gharleghi, B. (2015). Determinants of the Financial Literacy among College Students in Malaysia. International Journal of Business Administration, 6(3), 15-24. https://doi.org/10.5430/ijba.v6n3p15

Atkinson, A., \& Messy, F. A. (2011). Assessing financial literacy in 12 countries: An OECD/INFE international pilot exercise. Journal of Pension Economics and Finance, 10(4), 657-665. https:/ / doi.org/10.1017/S1474747211000539

Beal, D. J., \& Delpachitra, S. B. (2003). Financial Literacy Among Australian University Students. Economic Papers: A Journal of Applied Economics and Policy, 22(1), 65-78. https://doi.org/10.1111/j.1759-3441.2003.tb00337.x

Bhargava, N. R., Mittal, S., \& Kushwaha, V. S. (2017). Impact of Financial Literacy on Personal Financial Management Based on Occupation. Journal of Advance Management Research, 05(04), 134-147.

Birari, A., \& Patil, U. (2014). Spending \& Saving Habits of Youth in the City of Aurangabad. The SIJ Transactions on Industrial, Financial \& Business Management, 2(3), 158-165. https:/ / doi.org/10.9756/sijasree/v4i5/0203230101

Brown, S., \& Taylor, K. (2011). Household Finances and the Big Five Personality Traits. IZA Discussion Paper, (6191). https:/ / doi.org/10.1109/TENCON.2016.7848175

Chen, H., \& Volpe, R. P. (1998). An Analysis of Personal Financial Literacy Among College Students. Financial Services Review, 7(2), 107-128. https:// doi.org/10.3788/CJL201643.0811001

Chotimah, C., \& Rohayati, S. (2015). Pengaruh Pendidikan Keuangan Di Keluarga, Sosial Ekonomi Orang Tua, Pengetahuan Keuangan, Kecerdasan Spiritual, Dan Teman Sebaya Terhadap Manajemen Keuangan Pribadi Mahasiswa S1 Pendidikan Akuntansi Fakultas Ekonomi Universitas Negeri Surabaya. Jurnal Pendidikan Akuntansi (JPAK), 3(2), 1-10.

Donnelly, G., Iyer, R., \& Howell, R. T. (2012). The Big Five personality traits, material values, and financial well-being of self-described money managers. Journal of Economic Psychology, 33(6), 1129-1142. https:// doi.org/10.1016/j.joep.2012.08.001

Durband, D. B. \& Britt, S. L. (2012). Student Financial Literacy: Campus-Based Program Development. New York: Springer. 
Ergün, K. (2018). Financial literacy among university students: A study in eight European countries. International Journal of Consumer Studies, 42(1), 2-15. https:// doi.org/10.1111/ijcs.12408

Ewen, R. B. (1998). Personality: A topical approach: Theories, research, major controversies, and emerging findings. New Jersey: Lawrence Erlbaum Associates Publishers.

Fatimah, N. (2018). Pengaruh Pembelajaran Akuntansi Keuangan, Literasi Keuangan, dan Pendapatan Terhadap Perilaku Keuangan Mahasiswa Fakultas Ekonomi Universitas Muhammadiyah Gresik. Jurnal Pendidikan Akuntansi (JPAK), 6(1), 48-57.

Herdjiono, I., \& Damanik, L. A. (2016). Pengaruh Financial Attitude, Financial Knowledge, Parental Income terhadap Financial Management Behavior. Manajemen Teori Dan Terapan, 1(3), 226-241.

Humaira, I., \& Sagoro, E. M. (2018). Pengaruh Pengetahuan Keuangan, Sikap Keuangan, Dan Kepribadian Terhadap Perilaku Manajemen Keuangan Pada Pelaku Umkm Sentra Kerajinan Batik Kabupaten Bantul. Nominal, 7(1), 96-110. https://doi.org/10.21831/nominal.v7i1.19363

Jess, F. \& Gregory, F. (2014). Teori kepribadian = theories of personality. Jakarta: Salemba Humanika.

Kholilah, N. Al, \& Iramani, R. (2013). Studi Financial Management Behavior Pada Masyarakat Surabaya. Journal of Business and Banking, 3(1), 69-80. https:// doi.org/10.14414/jbb.v3i1.255

Laily, N. (2013). Pengaruh Literasi Keuangan Terhadap Perilaku Mahasiswa Dalam Mengelola Keuangan. Journal of Accounting and Business Education, 1(4). https:// doi.org/10.26675/jabe.v1i4.6042

Lajuni, N., Bujang, I., Karia, A. A., \& Yacob, Y. (2018). Religiosity, Financial Knowledge, and Financial Behavior Influence on Personal Financial Distress Among Millennial Generation. Jurnal Manajemen Dan Kewirausahaan, 20(2), 92 98. https:// doi.org/10.9744/jmk.20.2.92-98

Lantara, I. W. N., \& Kartini, N. K. R. (2015). Financial Literacy Among University Students: Empirical Evidence From Indonesia. Journal of Indonesian Economy and Business, 29(3), 247-256. https://doi.org/10.22146/jieb.10314

Lown, J. M. (2008). The Role of Retirement Personality Type in Motivating Women to Plan for Retirement, (93), 2-11.

Lusardi, A., Mitchell, O. S., \& Curto, V. (2010). Financial Literacy among the Young. The Journal of Consumer Affairs, Vol. 44(No. 2), 358-380.

Norvilitis, J. M., Merwin, M. M., Osberg, T. M., Roehling, P. V, Young, P., \& Kamas, M. M. (2006). Personality Factors, Money Attitudes, Financial Knowledge, and Credit-Card Debt in College Students. Journal of Applied Social Psychology, 1395-1413.

Richins, M. L., \& Dawson, S. (1992). A Consumer Values Orientation for Materialism and Its Measurement: Scale Development and Validation. Journal of Consumer Research, 19(3), 303. https:/ / doi.org/10.1086/209304

Robb, C. A., \& Sharpe, D. L. (2009). Effect of Personal Financial Knowledge on College Students' Credit Card Behavior. Journal of Financial Counseling and Planning, 20(1), 25-43. https://doi.org/10.1007/ s10834-011-9259-y

Rohman, A. (2016). Budaya Konsumerisme dan Teori Kebocoran di Kalangan Mahasiswa. KARSA: Jurnal Sosial Dan Budaya Keislaman, 24(2), 237-253. https:// doi.org/10.19105/karsa.v24i2.894 
Sarath Chandran, M. C., \& Chandran, R. (2018). Effect of financial literacy on the personal financial management of IT employees in Kerala. International Journal of Business and Management Invention (IJBMI), 7(8), 67-74.

Sina, P. G. (2014). Tipe Kepribadian Dalam Personal Finance. Jibeka, 8 No.1(1), 1-6.

Subiaktono. (2013). Pengaruh Personality Traits Terhadap Perencanaan Keuangan Keluarga. Jurnal Dinamika Manajemen, 4(2), 149-160. https:// doi.org/10.15294/jdm.v4i2.2759

Sugiyono. (2016). Metode Penelitian Kuantitatif, Kualitatif dan R\&D. Bandung: PT Alfabet.

Yushita, A. N. (2017). Pentingnya Literasi Keuangan Bagi Pengelolaan Keuangan Pribadi. Jurnal Nominal, VI(1), 11-26. 